\title{
The Orientalist Hans Friedrich Overbeck 1882-1942: His Entomological Work, Prisoner-of-War Experiences and Known Photographic Images
}

\begin{abstract}
ROBERT W. TAYLOR*
The Southeast Asia-based German mercantile trader and Orientalist Hans Friedrich Overbeck (1882-1942) published four books and over 60 articles on Malay cultural subjects, the latter largely in the Journal of the Straits (and Malayan) Branch of the Royal Asiatic Society. Before World War I he collected Asian ant specimens for Dresden entomologist Hugo Viehmeyer. Overbeck was arrested by the British Singapore administration as an enemy alien in 1915 and interned for almost five years in Australia, where his Malayological and entomological activities continued. After returning to Asia in 1919 he regularly contributed insect specimens to the Museum für Tierkunde, Dres-den. He was arrested, again as an enemy alien, in 1940 by the Netherlands East Indies authorities, and died a prisoner in 1942 when the steamer Van Imhoff was sunk by a Japanese aircraft while transporting German prisoners of war to India. Because his possessions were lost in this disruption, and in the firebombing of his parental home in Bremen in 1944, it has long been assumed that no photographs of Overbeck existed. Seven recently discovered archival images are reproduced here.
\end{abstract}

\section{Introduction}

Hans Friedrich Overbeck (1882-1942) is known to Malayologists through his books and scholarly publications on Malay language, culture, poetry and ethnography, his first-transcriptions of traditional oral culture and the collections of his papers held in Malaysian and Indonesian archives. ${ }^{1}$ He resided in Singapore and the Dutch East Indies for most of his adult life from 1903 to 1942, published regularly in the Journal of the Straits (and Malayan) Branch of the Royal Asiatic Society, and was a member of the Society from 1913 until his death in 1942. Overbeck was a prisoner of war in both world wars: in Singapore and New South Wales, Australia, in WWI and Sumatra in WWII. He died a prisoner at sea off southern Sumatra just 43 days after declaration of the 1942-5 Pacific conflict.

\footnotetext{
Robert W. Taylor is an Adjunct Professor of Biology at the Australian National University and a former Chief Curator and current Honorary Fellow of the Australian National Insect Collection, CSIRO, Canberra. He has published over 120 papers, largely on the systematics and evolution of ants, and has conducted field and taxonomic research on Malaysian ants, notably in Borneo. Postal address: Building 46, Research School of Biology, The Australian National University, Acton, ACT 0200, Australia. Email: bob.taylor@homemail.com.au.

1 Kratz (1976, 1979, 1980); Overbeck, Ridhwan \& Kratz (2004).
} 
'H. Overbeck' is also known to entomologists, especially myrmecologists (who study ants), because of citations as a collector of Asian and Australian insects discussed in taxonomic papers, and familiarity of the species name 'overbecki'. Among the ants alone a genus and 13 species or subspecies have been named in his honour. ${ }^{2}$

This paper summarizes information about Overbeck's experiences gathered by the author as an entomologist and researcher in Australian archives, which it is feared might otherwise be lost to future scholars.

Few entomologists know of Overbeck's Malayology, and his entomological activities are essentially unknown to Orientalists. They were revelational, for example, when I discussed them at a 1994 conference on his life and work. ${ }^{3}$ One prospective speaker even contended that 'This entomologist is another Hans Overbeck, he cannot be "my" Hans Overbeck.' ${ }^{4}$ Most of the audience knew little of Overbeck's history. None (including Overbeck's nephew Hans Carl Overbeck and his wife Gisela) had previously seen his image, and it was then generally believed that no photographs of him existed - until I projected his then recently discovered 1915 Australian prisoner identification photograph, published here for the first time, and a later photograph taken in Semarang, Java around 1922, which had been previously published in an obscure work. Six other very recently discovered archival prison-camp photographs of Overbeck are discussed below.

Overbeck's early years were spent in Bremen, Germany, where civic records recognize Hans Friedrich Overbeck, born 28 March $1882 .{ }^{5}$ His birthplace is given as Bremen, which might be true of registration rather than the event (see below). His father maintained a family mercantile company Firma Carl Friedrich Overbeck. Information gathered separately by Wilfried Wagner has Overbeck's birthplace as Rangoon, Burma ${ }^{6}$ (if true, the registration in Bremen was possibly a formality affirming citizenship), and that his father had been a rice broker and German Consul there. ${ }^{7}$

Hans is reported to have attended the 'Old High School' in Bremen until matriculation. In 1901, aged 19, he reported employment as a 'trading apprentice' (Handlungslehrling). ${ }^{8}$ He moved to Singapore in 1904, aged 22, to join the Singapore office of the prominent Hamburg-based mercantile house Behn, Meyer \& Co., ${ }^{9}$ and to the Netherlands East Indies in 1908. He travelled widely as Behn, Meyer general agent for the Malay Archipelago (Generalvertreter für Insulinde)

2 Bolton et al. (2007).

3 A gathering organized by Professor Dr Wilfried Wagner at Universität Bremen, August 1994.

4 Wilfried Wagner (pers. comm.).

5 Dr I. Müller, Staatsarchiv Bremen, pers. comm.

6 Wilfried Wagner (pers. comm.).

7 In addition, a British Foreign Office bulletin in the London Gazette for 1871 reports that 'The Queen has been pleased to approve of ... Mr C. F. Overbeck as consul at Rangoon for His Majesty the Emperor of Austria.'

8 In papers related to service in Germany as an army reservist during 1902/03.

9 A company still extant in Singapore, where it has been represented since 1840. 
until retirement. ${ }^{10}$ He visited Bremen on home-leave during 1911/12. Ulrich Kratz confirms that Overbeck resided primarily in Singapore before 1914, and that he at one time applied for pre-WWI residence in the Netherlands East Indies. ${ }^{11}$

Hans Overbeck first achieved published notice in 1913 when the Dresden myrmecologist Hugo Viehmeyer dedicated a Javanese ant, Pseudolasius overbecki, to him as its collector. ${ }^{12}$ Several years later, the same author reviewed a substantial collection of ants gathered by Overbeck in Singapore, Johore and Java between November 1912 and June 1914,13 and recognized Overbeck's scientific contribution by naming the newly described genus Overbeckia in his honour. ${ }^{14}$ Five new species or subspecies in other ant genera were named 'overbecki', and it was noted that Overbeck's entomological activities had been interrupted by the 1914-18 World War.

\section{Overbeck's Imprisonment and Entomological Collecting, 1914-1919}

My investigations ${ }^{15}$ confirm that Hans Overbeck was one of many German and Austro-Hungarian men comprehensively rounded up from British 'possessions' in Southeast Asia following the declaration of war with Germany in August 1914 and eventually held as 'enemy aliens' at Tanglin Barracks Prison Camp, Singapore. ${ }^{16}$ They were later joined by a group of 20 crewmen from the infamous German naval Indian Ocean commerce raider SMS Emden, whose presence was to influence future events. ${ }^{17}$ During March/April 1915271 Tanglin prisoners, including Overbeck, were transported by ship to Australia and interned at Holsworthy Concentration Camp at Liverpool, near Sydney. There they joined many compatriots previously arrested in Australia and German New Guinea. ${ }^{18}$

The hurriedly organized move to Sydney followed a deadly mutiny by Indian Army troops of the Singapore Garrison on 15 February 1915 which threatened

10 Pre-WWII Behn, Meyer Company movement records are lost. Overbeck's travels would likely have ranged from Rangoon and Bangkok, east to Manila and south to Surabaya and Makassar (P-J. Schönberg, pers. comm.). His writings mention the collecting of Malay literature as far east as the Moluccas.

11 Kratz $(1976,1979)$.

12 Viehmeyer (1913).

13 There were 300 reported vials of specimens, with many colony series and 100 pages of notes on nest architecture and life history.

14 Viehmeyer (1917).

15 Conducted at the Australian War Memorial, National Library of Australia, National Archives of Australia, Canberra, and Mitchell Library, Sydney.

16 This wide-ranging operation netted over 60 Behn, Meyer employees from offices in Singapore, Penang, Ipoh, Bangkok, Rangoon and Sandakan (records from archived prisoner list, fn 60, below).

17 The sailors were apprehended off southern Sumatra in December (about a month after the destruction of Emden by HMAS Sydney at Cocos Keeling Island) as prize crew of the captured British collier Exford, which had serviced Emden since mid-October.

18 Fischer (1984, 1989). 
the safety of the internees, one of whom was killed when the camp was breached. The disturbance enabled a number of prisoners to quit the camp; it resulted in the discovery of an almost completed escape tunnel and suspicion that prisoners had fomented the mutiny by encouraging its leaders. The chief suspects were Emden Lieutenant Julius Lauterbach, with August Diehn and Adolf Schönberg who, like Overbeck, were employed by Behn, Meyer. These three individuals escaped Tanglin during the mutiny, eventually to reach Sumatra and beyond. ${ }^{19}$

Overbeck was at Holsworthy until August 1915 when, following much social, political and sometimes murderous ethnic conflict in the crowded camp, a number of prisoners-mostly Germans, including the Emden men-were transhipped to isolated Trial Bay on the north coast of New South Wales, to be accommodated in a disused, stone-built former civilian prison, Trial Bay Gaol. ${ }^{20}$ Two and a half years later (in May 1918), the Trial Bay prisoners were returned by railway to a new, segregated 'Eastern' compound at Holsworthy. ${ }^{21}$ After another year, on 29 May 1919, during the World War armistice, they were shipped under heavy guard on the vessel SS Kursk via Durban, the Suez Canal and Plymouth to Rotterdam (22 July), and thence by special train to Germany.

Between 1922 and 1925 five articles resulting from Viehmeyer's research on ant specimens collected by Overbeck in Australia were published. In the first, the new genus Peronomyrmex, with type species $P$. overbecki, was described from Trial Bay. $^{22}$ Following Viehmeyer's death in 1921,23 the last four papers were compiled by his entomological associates Karl Heller and the famous Swiss psychologist and myrmecologist August Forel. ${ }^{24}$ Three species or subspecies were named for Overbeck and the introduction states that he had collected the specimens for Viehmeyer while interned as a prisoner of war at Liverpool and Trial Bay. Forty-five new ant species or subspecies in twenty genera of six subfamilies were described. Trial Bay was type-locality for twenty-four taxa, Liverpool for nineteen.

Work parties ranged beyond the camps at both Holsworthy and Trial Bay, and such activity would arguably have provided Overbeck ample opportunity for insect collecting in natural bushland. In evidence, a recently discovered photograph shows him with other prisoners working under armed guard as firewood collectors outside the Trial Bay camp perimeter.

19 Tarling (1982); Harper \& Miller (1984); Helfferich (1983); Lauterbach (1917). The garrison troops were at the time shortly to move to Hong Kong. Lauterbach convinced them, via secret meetings with an influential havaldar in the private prison quarters afforded him as a naval officer, that they were in fact destined for Europe to fight co-religionist Turks. Lauterbach happily encouraged their remarkable belief that Kaiser Willhelm II had embraced Islam and adopted the Muslim name 'Haji Mohammed Guillano'.

20 Neil (1975); Poole and Poole (1990).

21 This move followed alarm that the German mystery ship Wolf, known recently to have laid mines in the Tasman Sea, would attempt to rescue the Emden sailors from Trial Bay, and a suspected over-flight of the gaol by Wolf's aptly named seaplane Wolfchen ('wolf child').

22 Viehmeyer (1922). Peronomyrmex now has three recognized species known from only five specimens (Shattuck, 2006).

23 Heller (1921a).

24 Viehmeyer (1924a,b, 1925a, b) 
Overbeck collected other Australian insects. Heller, for example, described a new beetle genus from Liverpool, collected 'daselbst während seiner Internierung im Konzentrationslager von Herrn H. Overbeck' ${ }^{25}$

\section{Asian Entomological Work}

Following the 1919 repatriation to Germany Overbeck returned promptly to Asia to resume his former Behn, Meyer employment, advance his Malayological research and further his entomological activities.

Comments in later entomological papers record that he soon resided in the Netherlands East Indies. Heller referred to 'H. Overbeek (sic!), Bremen (Jetzt in Niederl. Indien)', 26 and similar remarks were made by Viehmeyer and Horn and Kahle. $^{27}$ The latter state that Overbeck donated Javanese insects, especially beetles, to the Museum für Tierkunde, Dresden, from 1920.

In 1924 Overbeck published in JMBRAS a list of the ants of Singapore and neighbouring areas based on the collection reviewed in Viehmeyer's 1917 report, complete with notes on his 1912-14 collecting methods and sites, and indicating that he had lived at 7th mile, Bukit Timah Road, on an area of about 15 acres planted with fruit trees, coconut palms and rubber trees. He reports experiments on the rearing of colonies from queen ants caught at light, and support from I. H. Burkill, director of the Singapore Botanic Gardens. He declared that 'The whole work and further plans were stopped by the outbreak of the war.' 28

In 1925 Overbeck published in Germany an idealistic article on the potential importance to science of the collecting activities of expatriate Germans and the need for a national institute to receive their accessions. ${ }^{29}$ This article was later reprinted in Batavia (Jakarta). ${ }^{30}$ Overbeck's now regular contributions of specimens to the Dresden Museum were said by van Emden to be motivated by the ideals expressed in these essays. ${ }^{31}$

Overbeck was entomologically active in Java at least until 1938, when he collected the original specimens of several weevil species described by Heller. ${ }^{32}$ Papers featuring East Indies insects collected by him include those of Hanitsch on cockroaches; 33 Kutter on ants; ${ }^{34}$ van Emden and Heller \& Günther on beetles; 35 and Günther on grasshoppers. ${ }^{36}$ A number of species described in these works

\footnotetext{
25 Heller (1921b).

26 Ibid.

27 Viehmeyer (1924a); Horn and Kahle (1935-7).

28 Overbeck (1924).

29 Overbeck (1925a).

30 Deutsche Wacht, 12/1: 8-11 (1926).

31 van Emden (1934).

32 Heller (1940).

33 Hanitsch (1930).

34 Kutter $(1931,1932)$.

35 van Emden (1934); Heller and Günther (1936).

36 Günther (1939). The Swiss apothecary and myrmecologist Heinrich Kutter received ant specimens directly from Overbeck (pers. comm., 1968). The other authors named were all associated with the Dresden Museum.
} 
were named 'overbecki' and several genera new to science were included. Many of the specimens were collected at light in Overbeck's house and garden at Yogyakarta. ${ }^{37}$

The origins of Overbeck's entomological interests are unknown. His focus on ants might have been encouraged by Viehmeyer's book Images from the Life of Ants. ${ }^{38}$ There is no evidence in relevant reports of meetings (published in the journal Idea) that he was associated with the Buitenzorg (Bogor) based NederlandschIndische Entomologische Vereeniging, nor is he recorded in relevant issues of Tijschrift voor Entomologie as a member of the Nederlandsche Entomologische Vereeniging. Arrangements to gather ants for Viehmeyer seem likely to have originated during Overbeck's confirmed 1911/12 European furlough from his position in Singapore, since both Viehmeyer and Overbeck date the collecting from November 1912, and the first Viehmeyer paper featuring Overbeck specimens appeared in 1913.39

Overbeck's extant record and typewritten correspondence with the Museum für Tierkunde reveals that the first post-war insect specimens were received in 1919 (judging from his date of repatriation to Germany, these presumably included the Australian ants). ${ }^{40}$ The earliest surviving letter is dated 13 August 1925 . The record breaks from 1927 to 1932 and resumes from 1933 to 1939. Dr Rolf Hertel, the former Museum Director, considered the correspondence to represent an unusually interested amateur with limited scientific knowledge. ${ }^{41}$ There is much detail regarding collection sites, dates and biological particulars. Included photographs of insects are mentioned, but these were reportedly lost during WWII. Overbeck collected insects, spiders and scorpions, and with few exceptions refused requests for specimens representing other groups. Archived postcards show that he was forcefully impatient if receipt of specimens was not promptly confirmed. He complains of a lack of interest by the Dutch in his work, but acknowledges 'apprenticeship' as an insect collector in central Java and, later, Sumatra with H. Jacobsen (who died in 1925) and good relations with Maurits Lieftinck, sometime director of Buitenzorg Museum. Overbeck's cooperation with the Dresden Museum apparently began through Viehmeyer, who was a local schoolmaster and member of the Entomologischen Verein zu Dresden, ${ }^{42}$ and developed with Heller, a curator at the museum. Viehmeyer's ant collection, including the Overbeck accessions, is now in the Humboldt Museum (Museum für Naturkunde), Berlin. 43

\footnotetext{
37 van Emden (1934).

38 Viehmeyer (1908).

39 Viehmeyer (1917); Overbeck (1924).

40 Copies provided to Wilfried Wagner and the author by former Museum Director Dr R. Hertel.

41 pers. comm.

42 Heller (1921a).

43 It was eventually sold to that institution by his widow (ref.: Dresden Museum correspondence).
} 


\section{Overbeck's Life in Asia and Malayological Studies}

The Dresden Museum letters and Overbeck's publications contain some personal details. He worked for Behn, Meyer from the age of twenty-one (1903), and was apparently well-to-do in Singapore before the Great War. He referred to the years there before 1914 as his 'golden years'. In post-war Java he regularly visited plantations as a trader (Kaufmann). He mentions having been a merchant for thirtythree years when he retired from Behn, Meyer at age 49 in 1932. He then lived modestly, having been financially reduced twice, first by war and then by German inflation. Declining eyesight restricted collecting largely to his garden, and in later life he rarely travelled beyond his home in Yogyakarta. He recalls two and a half years detention at Trial Bay, and his 'less happy' stay at Holsworthy. Overbeck never married.

While a prisoner in Australia Overbeck compiled his major work, a twovolume German translation of the great Malay epic Hikayat Hang Tuah, despite the avowed lack of many desired reference sources. ${ }^{44}$ His letters mention that he had documented 1500 Javanese children's songs and 175 theatrical pieces, and that he had studied Aboriginal language while at Trial Bay, implying perhaps that the prisoners had (otherwise unreported) access to local indigenous Australians. He was a fluent linguist and published in German, Dutch, English and Malay. As an enthusiastic photographer he was ever equipped with the latest available Leica camera. ${ }^{45}$ His second and third books are illustrated with his photographs. ${ }^{46}$ It is suspected that his photographic collection was appropriated by the Japanese military in 1942 and might still survive in Japanese archives. ${ }^{47}$ Overbeck's profusely illustrated, very rare last ethnographic book on Javanese girls' games and children's songs was published in Yogyakarta not long before arrival of the invading Japanese. ${ }^{48}$

Following the Great War Overbeck lived in Java, first in Semarang, where he acted for two years as German Consul, and later (from 1925) in Surabaya. He retired as Behn, Meyer Director-General for South-East Asia, and soon moved to Yogyakarta. ${ }^{49}$ The Dresden Museum correspondence includes detailed accounts (sent by Overbeck with consignments of specimens) of several post-retirement insect-collecting expeditions to localities in Java.

Between the wars Overbeck published four books on Malayological subjects ${ }^{50}$ and 67 papers and book reviews, mostly in JSBRAS and JMBRAS, some under the pseudonym 'Si Anoe'. His writings discuss 'rummaging' in the Malay bookshops and markets of Arab Street, Singapore, in Batavia and elsewhere seeking rare documents. He names various prominent Malayologists with whom he corresponded

\footnotetext{
44 Overbeck (1922).

45 Hans Carl Overbeck (pers. comm.).

46 Overbeck (1925b, 1927).

47 Ulrich Kratz (pers. comm.). WWII Japanese military frequently collected such material for its possible intelligence value (S. Kuribayashi, pers. comm.).

48 Overbeck (1938/9).

49 Helfferich (1983).

50 Overbeck (1922, 1925b, 1927, 1938/9).
} 
or was acquainted, mentions discussions with Malay copyists and scholars, and that his library was regularly consulted by other researchers.

Hans Overbeck, his Malay studies, his books published before 1938, and the circumstances of his death are mentioned in the official Behn, Meyer company history. ${ }^{51} \mathrm{He}$ was considered 'more scholar than merchant, but gave his best to the firm'. Overbeck is included in three small photographic plates.

\section{The Pity War Distils}

Overbeck was again incarcerated as an enemy alien by the Netherlands East Indies authorities following the German invasion of the Netherlands in May 1940. He was held at prison camps near Ngawi, Java and at Allas Vallei, Sumatra, where family correspondence transmitted by the German Red Cross shows him to have been deeply pessimistic and depressed. ${ }^{52}$ He was transferred with 364 other Allas prisoners on 15 January 1942 to the steamer Van Imhoff for shipment from Sibolga, Sumatra, to Bombay, in a move to preclude collaboration between former East Indies German residents and the Japanese, then advancing rapidly southwards towards Singapore (which fell on 15 February). Van Imhoff was one of three vessels, each carrying the personnel of a separate prison camp. The ship was bombed by a Japanese aircraft south of Nias on 18 January, and sank slowly following the departure of the 120-member Dutch crew and military guards in five lifeboats allegedly with unoccupied space. ${ }^{53}$ The abandoned prisoners escaped the closed afterdeck and barbed-wire cages confining them in the holds and some departed the ship, either on a raft constructed from furniture or in the single remaining lifeboat which had been left by the crew jammed in its davits. Fifty-five men from the lifeboat survived by reaching southern Nias after being denied assistance by two Dutch vessels encountered en route. The other prison ships reached India safely. Unlike them, Van Imhoff was not marked for protective recognition by Japanese ships or aircraft, and the Japanese had not been notified that she was carrying (Japanese- allied) German prisoners. The classic account of the notorious Van Imhoff incident (which is represented there and elsewhere as a war crime) was published in 1965 by the German news magazine Der Spiegel, 54 and a comprehensive history of WWII incarceration of German ex-residents in the Netherland Indies, including the Van Imhoff circumstances, by van Heekeren. ${ }^{55}$ For more recent accounts see Geerken and Gräbner. 56

The entry 'Overbeck, Hans Friedrich, born 1882' appears in a list of Van Imhoff victims later compiled by the Netherlands authorities, 57 and in an official German Foreign Office list of 329 named deceased, reproduced by Gräbner. ${ }^{58}$

51 Helfferich (1983).

52 Kindly provided by Wilfried Wagner.

53 Some accounts implicate a Japanese surface vessel or submarine. Van Heekeren's (1983) authority is accepted here.

54 Anon. (1965).

55 van Heekeren (1983).

56 Geerken (2010); Gräbner (2012).

57 Karel E. Birkman, Royal Netherlands Embassy, Canberra (pers. comm.).

58 Gräbner (2012). 
Hans Overbeck died shortly before his sixtieth birthday in war-torn Southeast Asia where he had devoted much of his life and talent. This resolutely dedicated scholar and scientist had spent nearly 10 per cent of his life as a prisoner during two world wars, simply because, as a German, he was twice in the wrong place at the wrong time-in Singapore in 1914 and Yogyakarta in 1942.

\section{Overbeck's Appearance and Known Photographic Images}

A 1917 Australian document reports that Overbeck was $5 \mathrm{ft} 9$ in $(176 \mathrm{~cm})$ tall and 'slender', with fair hair and blue eyes. ${ }^{59}$

Fig. 1 depicts Hans Overbeck at age 33 in Sydney, soon after arrival as a prisoner from Singapore in 1915.60 Fig. 2, from the Behn, Meyer Company

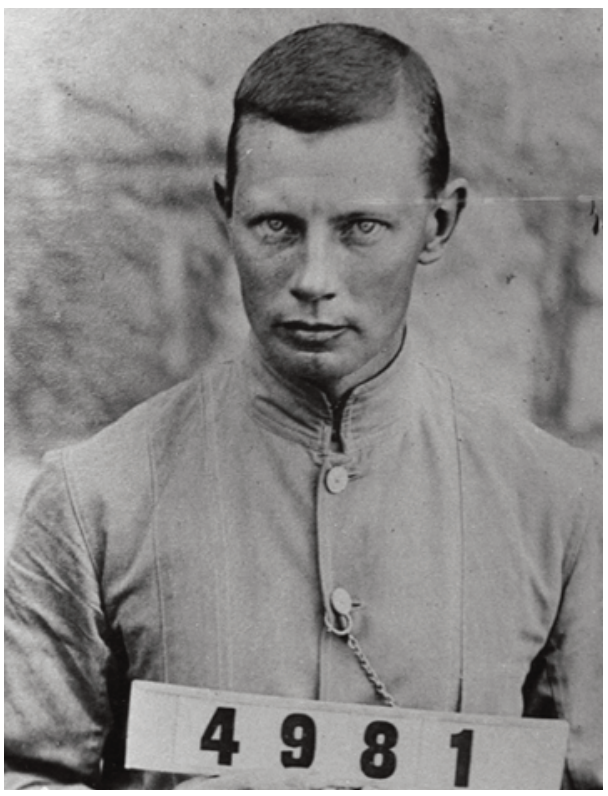

FIG. 1. Overbeck's prisoner identification photograph, aged 33, Sydney, Australia, 1915 (source: National Archives of Australia, Canberra).

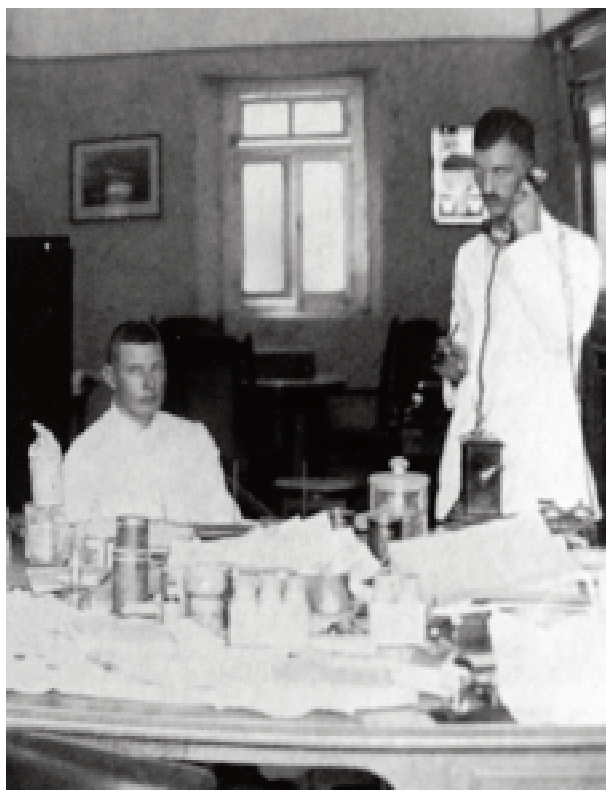

FIG. 2. Hans Overbeck aged c.40 (seated) with Behn, Meyer colleague Albrecht LorenzMeyer, Semarang, Java (undated, probably c.1922) (source: Helfferich, 1983).

59 Details from Overbeck's signed application for alien registration in Australia, prepared in anticipation of loss of 'enemy alien' status at the end of the war (Australian National Archives SP43/3NN, dated 8.1.1917). His dates of birth and entry into Australia are confirmed, Bremen is given as his birthplace, and a rubber-stamped attachment confirms repatriation on SS Kursk.

60 This image is from a large album (Australian National Archives, D3597 4981) containing photographs of 5,790 male World War I prisoners interned in Australia, with an accompanying list of their names and other details. 
historical volumes, is the only known, usable, formerly published image of Overbeck (aged about 40) in which he is identified by name. He is seen seated at the Behn, Meyer office in Semarang. 61 No other personal photographs are known to have survived his 1940-2 East Indies tribulations, the World War II upheavals of Behn, Meyer establishments in Singapore and Hamburg62 or the gutting of his parental family home in Bremen by incendiary bombing in $1944 .{ }^{63}$

Overbeck can, however, be recognized with reasonable confidence (by comparison with his authentically identified 1915 prisoner photograph) in five recently discovered WWI Australian prison camp images. He was first perceived by the author in two of these photographs following their publication by Helmi and Fisher. ${ }^{64}$ All of these pictures are the work of photographer Paul Dubotzki, a prisoner with Overbeck at Trial Bay and Liverpool. They were discovered in 2008 at Dorfen, near Munich, Germany, among the possessions of Dubotzki's descendent family, following inspirational archival work and field search by Australian researcher Nadine Helmi. Overbeck is depicted as an athletics bystander at Holsworthy (Fig. 3), as a firewood collector working with others under guard in

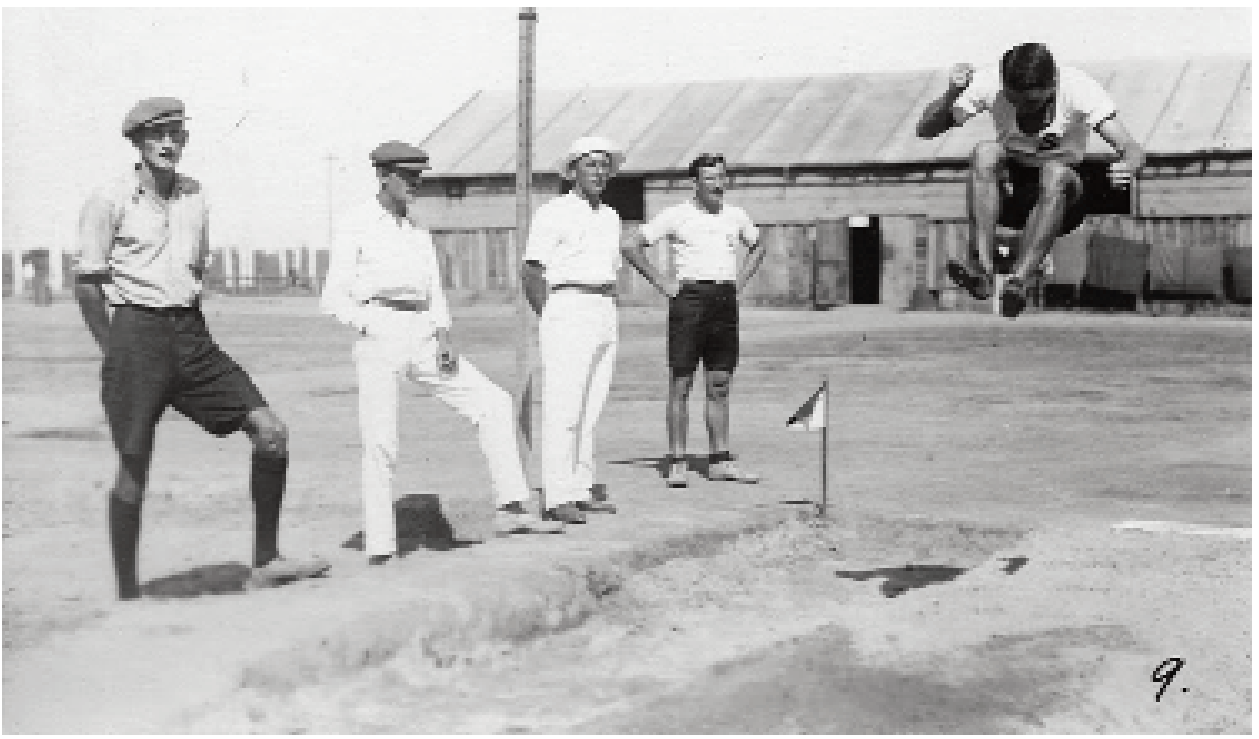

FIG. 3. Hans Overbeck (aged 33/36) (left) at Holsworthy Camp, NSW (1915 or, more likely 1918) (source: Migration Heritage Centre, Sydney). Photo attributed to Paul Dubotzki.

61 Helfferich (1983). Two other group photographs of Behn, Meyer personnel in the Helfferich history identify Overbeck in their captions, but are too reduced and obscure for use here.

62 Peter-Jochim Schönberg (pers. comm.).

63 Hans Carl and Gisela Overbeck (pers. comm.). Only one of Overbeck's former possessions survived the Bremen fire-bombing: his canteen of silver cutlery which had been stored in a bank vault. The outer walls of the burnt-out multi-storey inner-city family home survived sufficiently for post-war reconstruction of the interior-the restored building still stands.

64 Helmi and Fisher (2011). 
three related photographs from Trial Bay (Fig. 4), ${ }^{65}$ and as an actor on stage surrounded by harem 'girls' at the Trial Bay camp theatre (Fig. 5). Other aspects of the admirably vigorous social, recreational and commercial culture of prisoners at Trial Bay and Holsworthy are described and illustrated by Helmi and Fisher. 66

These photographs are the only known usable images of Hans Overbeck known to the author-his appearance is no longer a matter of conjecture!.

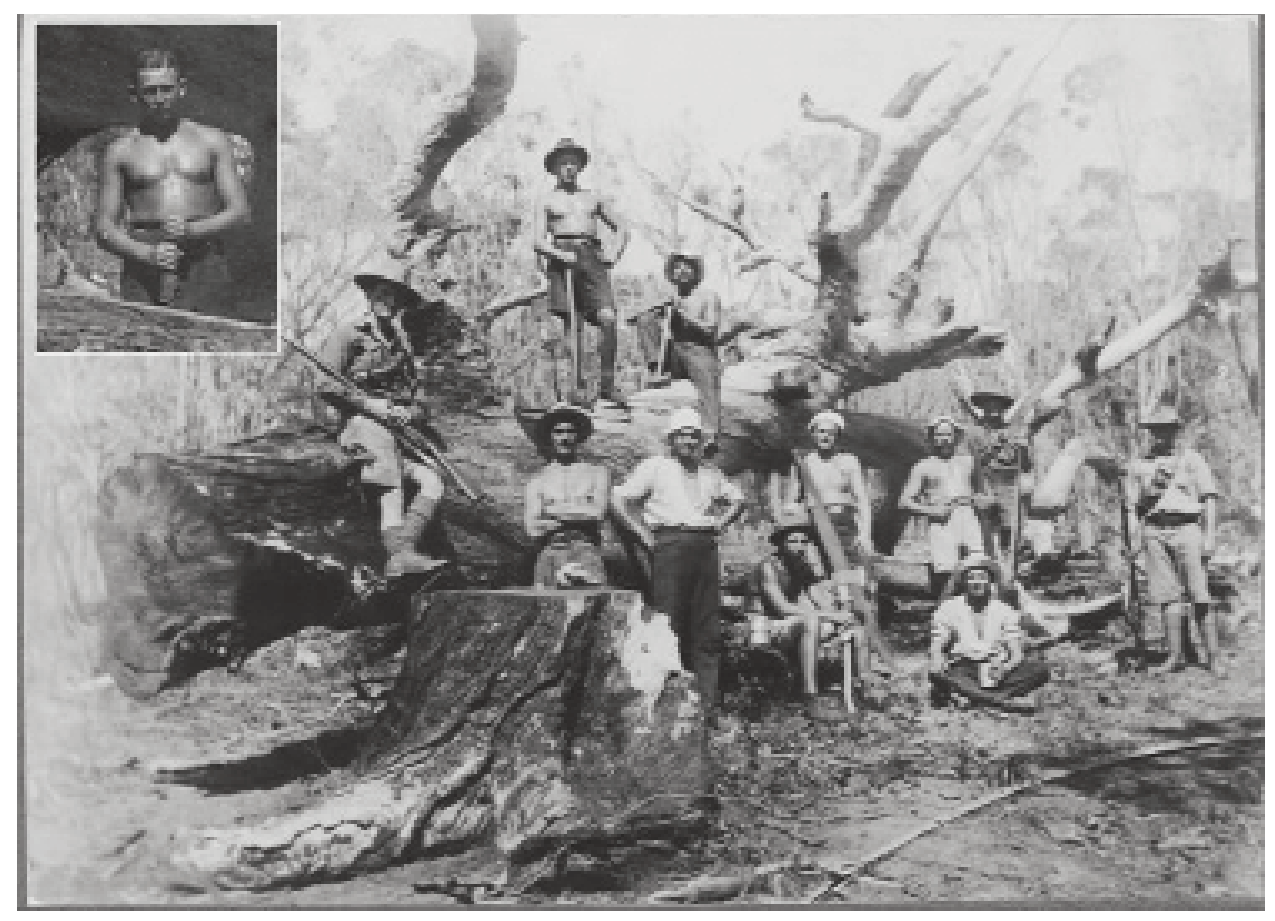

FIG. 4. Prisoners collecting firewood under armed guard outside the Trial Bay Camp perimeter (1916-1918). Hans Overbeck (aged 34/36) is top centre, bare-chested with hat. (Source: National Library of Australia, Canberra) Insert: Hans stands bare-headed at groundlevel in a second similar photograph (Source: Migration Heritage Centre, Sydney). Photos attributed to Paul Dubotzki.

65 The Fig 4 insert is from a second full image taken from the same vantage as Fig. 4 (the camera apparently on an unmoved tripod) with the personnel re-positioned. A third, uncopied, similar picture (Migration Heritage Centre, Sydney), depicts Overbeck placed as in Fig. 4, but seated and hatless. Many Dobrotzki pictures are opportunistic 'snapshots' but here he was clearly creatively deploying posed subjects, as likely also in the technically challenging Fig 3, and in Fig 5. Overbeck's repeated presence in these well-structured posed studies might indicate friendship between the two men, perhaps related to camera club activities at Trial Bay where Hans might have developed his passion for photography under 66 Ibid.

Dobrotzki's tutelage. 


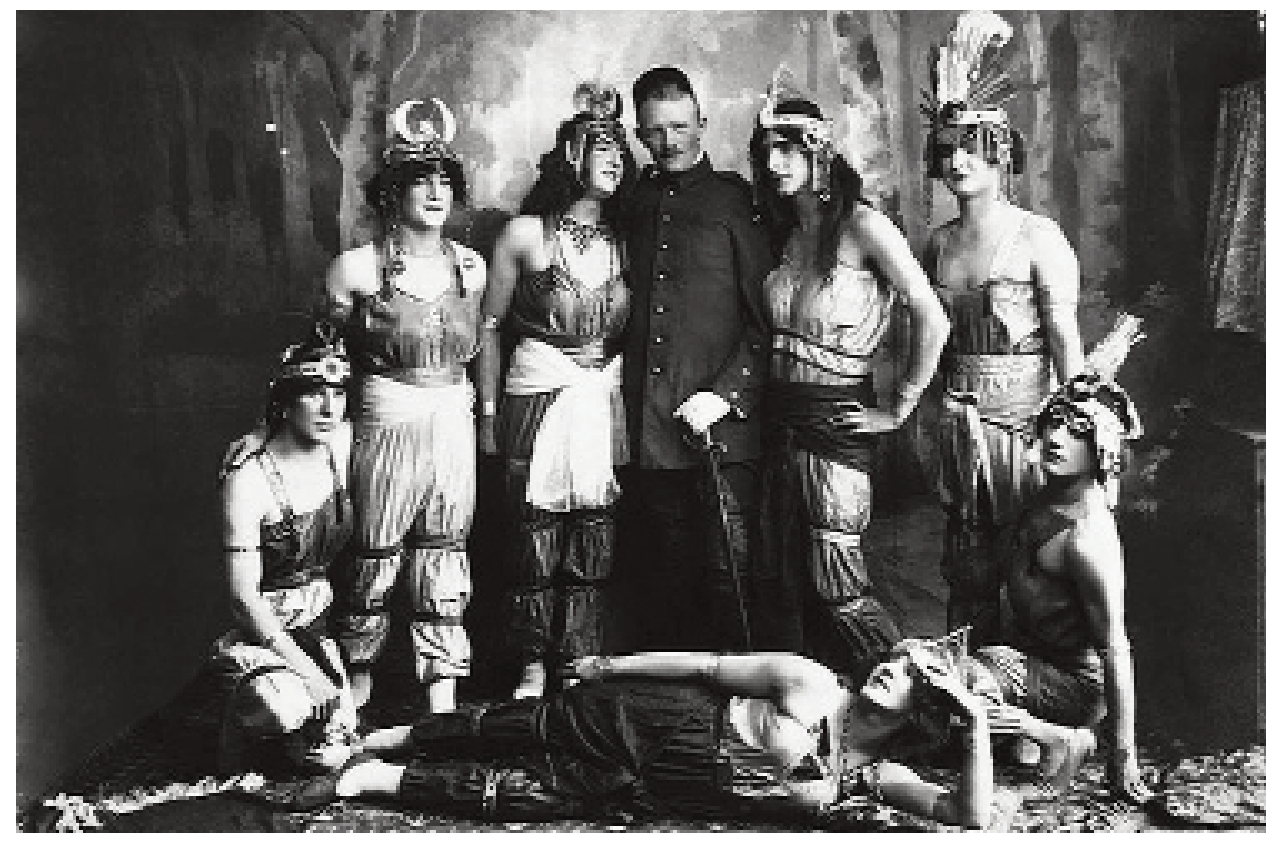

FIG. 5. Hans Overbeck the actor (centre, in male costume) Trial Bay Camp Theatre (19161918) (Source: Migration Heritage Centre, Sydney). Photo attributed to Paul Dubotzki.

\section{Acknowledgements}

Grateful thanks to Wendy Taylor; Hans Carl and Gisela Overbeck; Dr Wilfried Wagner, Universität Bremen; Dr E. Ulrich Kratz, University of London; PeterJochim Schönberg, Firma Otto Meyer, Hamburg; Drs Hertel and Müller and Karel E. Birkman, mentioned above; Jochen Zeil; Denis Hawkins; Edward O. Wilson, Steve Shattuck, Nadine Helmi; Gerhard Fischer; Stephen Thompson, Migration Heritage Centre, Sydney; Nicolette Suttor, National Library of Australia; Victoria Gwyn and Lauren Hewitt, Australian War Memorial, Canberra; Jan Haywood, Arakoon State Recreation Area, Trial Bay, 67 an anonymous referee, staff of the archives and libraries mentioned, and the British Public Records Office, Kew; the Canberra embassies of Germany and the Netherlands and the Singapore High Commission. Attendance at the August 1994 Bremen meeting was supported by the German Embassy, Canberra, negotiated by Dr Rosalie Fabricius. The Dresden Museum correspondence and other papers were originally sourced by Wilfried Wagner to whom I am especially indebted. Copies of those documents and my biographical notes on Hans Overbeck are deposited with the National Library of Australia, Canberra.

67 Trial Bay Goal stands today as a popular tourist attraction in theArakoon State Recreation Area near Kempsie, NSW. 


\section{References}

Anon (1965), 'Kriegsverbrechen, Van Imhoff Untergang, das Totenschiff', Der Spiegel, 52: 42-4 (www.spiegel.de/spiegel/print/d-46275481.html).

Bolton, B., Alpert, G., Ward, P. S. and Nashrecki, P. (2007), Bolton's Catalogue of the Ants of the World, 1758-2005, CD-ROM. Cambridge, Massachusetts: Harvard University Press. See also: http://www.antwiki.org/Species_Accounts.

Fischer, G. (1984), 'Botany Bay revisited: the transportation of prisoners of war and civilian internees to Australia during the First World War', Journal of the Australian War Memorial, 5: 36-44.

(1989), Enemy Aliens: Internment and the Homefront Experience in Australia 1914-1920, St Lucia, Queensland: University of Queensland Press.

Geerken, H. H. (2010), A Gecko for Luck, Stoughton, Wisconsin: Books on Demand.

Gräbner, D. (2012), 'Die van Imhoff'-das Totenschiff: Geschichte und Mythos einer Weltkriegstragödie, Saarbrücken: Conte-Verlag.

Günther, K. (1939), 'Revision der Acrydiinae (Orthoptera), III. Sectio Amorphopi (Metrodorae Bol. 1887, aut.)', Abhandlungen und Berichte aus den Staatlichen Museum für Tierkunde und Völkerkunde in Dresden, 20: 16-335.

Hanitsch, R. (1930), 'Über eine Sammlung Malayischer Blattiden des Dresdener Museums (Orth.)', Stettiner Entomologische Zeitung, 91: 177-95.

Harper, R. W. E. and Miller, H. (1984), Singapore Mutiny, Singapore: Oxford University Press.

Helfferich, E. (1981-3), A Company History: Behn, Meyer \& Co. and Arnold Otto Meyer, transl. Heidi Hartmann and Douglas Earp, Hamburg: Hans Christians Verlag, 2 vols.

Heller, K. M. (1921a), 'Hugo Viehmeyer', Nekrolog der Naturwissenschaftlichen Gesellschaft ISIS in Dresden, 1920/21: xviii-xx.

(1921b), 'Neue Rhipiphoriden (Col. )', Tijdschrift voor Entomologie, 1920: $168-75$.

(1940), 'Indomalayische Rüsselkäfer II (Coleoptera, Curculionidae)', Arbeiten über Morphologische und Taxonomische Entomologie, 7: 92-113.

Heller, K. M. and Günther, K. (1936), ‘Über einige von H. Overbeck 1933/34 auf Java gesammelte Insekten', Tijdschrift voor Entomologie, 1936: 64-76.

Helmi, N. and Fischer, G. (2011), The Enemy at Home: German Internees in World War I Australia, Kensington, NSW: University of New South Wales Press.

Horn, W. and Kahle, I. (1935-7), 'Über entomologische Sammlungen, Entomologen \& Entomo-museologie', Teil 1-3, Entomologische Beihefte Berlin-Dahlem, 2-4: $1-536$.

Kratz, E. U. (1976), 'Hans Overbecks wissenschaftliches Werk, ein bio-bibliographischer Versuch', in H. Overbeck, Malaiische Chronik und Hang Tuah, neu herausgegeben von O. Karow, Koln: Diedrichs, pp. 344-53.

(1979), 'The Malay studies of Hans Overbeck', Indonesian Circle, 20: 17-24.

(1980), 'A brief description of the "Malay" manuscripts of the "Overbeck Collection" at the Museum Pusat, Jakarta', Journal of the Malaysian Branch of the Royal Asiatic Society, 53/1: 90-106.

Kutter, H. (1931), 'Forelophilus eine neue Ameisengattung', Mitteilungen der Schweizerischen Entomologischen Gesellschaft, 15: 471-4. 
(1932), 'Ameisen aus dem Museum zu Dresden', Mitteilungen der Schweizerischen Entomologische Gesellschaft, 15: 207-10.

Lauterbach, J. (1917), 1,000 Pf. Sterling Kopfpreis: tot oder lebendig, Berlin: Scherl.

Lochner, R. K. (1988), The Last Gentlemen of War: The Raider Exploits of the Cruiser Emden, Annapolis, Maryland: Naval Institute Press.

Neil, M. H. (1975), Trial Bay Gaol Public Works Prison and Wartime Detention Camp, Kempsey, NSW: Macleay River Historical Society.

Overbeck, H. (transl.) (1922), Hikayat Hang Tuah: Die Geschichte von Hang Tuah, München: Muller, 2 vols. Reprinted (1986) as Die Geschichte von Hang Tuah: Ein Erzählung aus dem 16. Jahrhundert über den Malaiischen Volkshelden, München: Beck.

(1924), 'A list of ants from Singapore and neighbouring places', Journal of the Malayan Branch of the Royal Asiatic Society 2/1: 25-40.

(1925a), 'Auslandshilfe. laien-gedanken über eine Zentralstelle für die Deutsche Wissenschaft', Tat: Wege zu freiem Menschentum, September 1925: 434-41.

(transl.) (1925b), Malaiische Erzählungen: Romantische Prosa-lustige Geschichten-Geschichten vom Zwerghirsch, Jena: Eugen Diederichs.

(transl.) (1927), Malaiische Weisheit und Geschichte: Einführung in die Malaiische Literatur-die Krone aller Fürsten die Chronik der Malaien, Jena: Eugen Diederichs.

(1938/39), Javaansche meisjesspelen en kinderliedjes, beschrijving der spelen Javaansche leiderteksten vertaling, bewerkt door H. Overbeck, Yogyakarta: Javainstituut.

Overbeck, H., Ridhwan, A. and Kratz, E. U. (2004), Hati Mesra: Pantun Melayu sebelum 1914, Kuala Lumpur: Dewan Bahasa dan Pustaka.

Poole, E. S. and Poole, A. G. (1990), 'Trial Bay Gaol: memorial to a humanitarian or monument to failure', Heritage Australia, Autumn 1990: 2-6.

Shattuck, S. O. (2006), 'A third species in the rare Australian ant genus Peronomyrmex Viehmeyer (Hymenoptera: Formicidae)', Zootaxa, 1194: 49-55.

Tarling, N. (1982), 'The merest pustule: the Singapore mutiny of 1915', Journal of the Malaysian Branch of the Royal Asiatic Society, 55/2: 26-59.

Thomas, L. (1931), Lauterbach of the China Sea: The Escapades and Adventures of a Seagoing Falstaff, Garden City, New York: Doubleday.

van Emden, F. (1934), 'Von H. Overbeck gefangene neue und bekannte Arten der Carabidae, Hydrophilidae, Georyssidae und Clavicornia (Col. )', Entomologische Blätter, 30: 193-200.

van Heekeren, C. (1983), Batavia seint: Berlijn: de geschiedenis van de Indische Duitsers in Nederlandse gevangenschap (2nd rev. and enlarged edn), Gravenhage: Nijgh \& van Ditmar.

Viehmeyer, H. (1908), Bilder aus dem Ameisenleben, Leipzig: Quelle and Meyer. (1913), 'Neue und unvollständig bekannte Ameisen der alten Welt', Archiv für Naturgeschichte, (A)79/12: 24-60.

(1917), 'Ameisen von Singapore beobachtet und gesammelt von H. Overbeck', Archiv für Naturgeschichte, (A)81/8: 108-68.

(1922), 'Neue Ameisen', Archiv für Naturgeschichte, (A)88/7: 203-20. 
(1924a), 'Formiciden der australischen Faunenregion', Entomologische Mitteilungen, 13: 219-29.

(1924b), 'Formiciden der australischen Faunenregion', Entomologische Mitteilungen, 13: 310-19.

(1925a), 'Formiciden der australischen Faunenregion', Entomologische Mitteilungen, 14: 25-39.

(1925b), 'Formiciden der australischen Faunenregion', Entomologische Mitteilungen, 14: 139-49. 